\title{
Epitrochlear lymphadenitis mimicking subcutaneous abscess
}

\author{
Sidney Ching Liang Ong, ${ }^{1}$ Phing Phing Tang ${ }^{2}$
}

${ }^{1}$ Radiology Department, Clinical Campus, International Medical University, Seremban, Negeri Sembilan, Malaysia

${ }^{2}$ Department of Otorhinolaryngology, Hospital Tengku Ampuan Rahimah, Klang, Selangor, Malaysia

Correspondence to Dr Sidney Ching Liang Ong, sidney_ong@yahoo.co.uk

Accepted 2 February 2018

\section{DESCRIPTION}

An 8-year-old boy presented with painful swelling at the distal left arm for 2 weeks and intermittent fever. He had no history of trauma, inoculation or insect bite. On examination, his temperature was $38.6^{\circ} \mathrm{C}$. There was a $4 \times 4 \mathrm{~cm}$ ill-defined swelling at the medial aspect of distal left arm, just above the elbow joint. It was erythematous, tender, firm and warm with restricted mobility. Pain was aggravated on moving the left elbow. There was no enlarged regional node, skin lesion or puncture wound. $\mathrm{He}$ was suspected to have subcutaneous abscess and was treated empirically with intravenous cloxacillin. Unfortunately he developed allergic reaction, and the antibiotic was changed to intravenous cefuroxime.

Total white count (TWC, $15 \times 10^{9} / \mathrm{L}$ ) and erythrocyte sedimentation rate (ESR, $69 \mathrm{~mm} /$ hour) were raised. Plain radiographs showed soft tissue swelling with normal underlying humerus. Ultrasound revealed a well-defined, lobulated, hypoechoic lesion measuring $17.6 \times 21.1 \times 22.4 \mathrm{~mm}$ just deep to the basilic vein. There was internal hyperechoic component but no mobile debris (figure 1) . Doppler mode showed florid intralesional signals at the echogenic portion (figure 2). Final diagnosis of epitrochlear lymphadenitis was made following ultrasound findings.

He remained afebrile throughout admission and had completed 3 days of intravenous cefuroxime before being discharged with oral cefuroxime for a week. The swelling subsided completely after antibiotics. Blood culture taken earlier was negative.

Similar cases have been reported involving children aged between 9 months and 12 years. All the lesions resolved completely after antibiotics. ${ }^{12}$

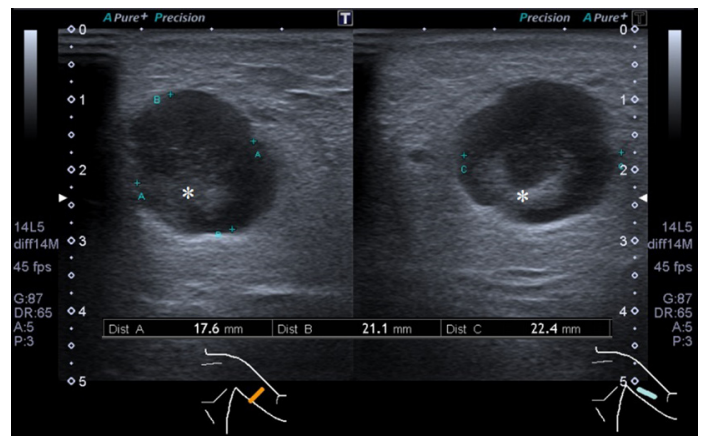

Figure 1 Sonographic images in transverse and longitudinal sections at the medial left arm showing a well-marginated, lobulated, hypoechoic lesion with central echogenic component (asterisks).

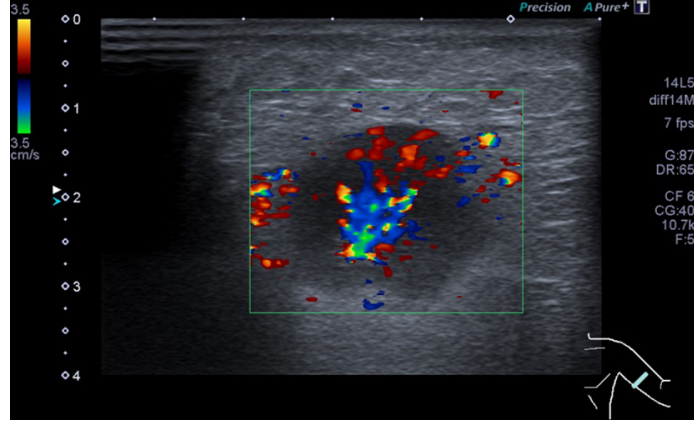

Figure 2 Doppler mode showing florid intralesional signals radiating from the echogenic component seen in figure 1.

Epitrochlear lymph nodes are the only superficial lymph nodes draining the upper extremities. The number varies from one to four, and they can be found at the medial aspect of the elbow, $4-5 \mathrm{~cm}$ above the humeral epitrochlea. Generally, epitrochlear nodes drain lymph from the medial aspect of the hand, but this is subject to wide interindividual variability. ${ }^{1-3}$

A puncture wound or skin lesion can usually be identified, and the most common causes are Gram-positive cocci (Streptococcus, Staphylococcus). ${ }^{12}$ Hence the initial choice of antibiotics is often penicillin-based. ${ }^{1}$ Other causes of epitrochlear lymphadenitis are tuberculosis, sarcoidosis, lymphoma and metastatic deposits. In certain endemic regions, filariasis and leprosy need to be considered. Differential diagnosis of extranodal causes of medial arm swelling includes tumours of nerves and vascular origin or soft tissue mass lesions such as lymphangioma, lipoma or haemangioma. $^{23}$

Radiographic findings are essential to assess the integrity of the underlying bone and may be useful in suspected cases of osteomyelitis. However, epitrochlear lymphadenitis and other non-skeletal causes of swelling will have similar appearances. Ultrasound assessment using high-frequency linear transducers is high yield and can demonstrate the typical appearance of an enlarged lymph node. ${ }^{2}$ Inflammatory markers (TWC, ESR, C reactive protein), blood culture and fine-needle aspiration will be able to confirm the causative organisms. Unfortunately in our case, blood culture was negative and no sample was obtained from the lesion as the patient responded remarkably with empirical antibiotics.

In conclusion, epitrochlear lymphadenitis is an uncommon cause of medial arm swelling. It should be considered as a differential diagnosis in appropriate clinical situations. 


\section{Learning points}

Epitrochlear lymphadenitis should be considered as a differential diagnosis in painful medial arm swelling.

- A source of infection such as a puncture wound or skin lesion can usually be identified.

- Common causative organisms are Gram-positive cocci (Streptococcus, Staphylococcus).

Contributors SCLO and PPT have contributed sufficiently to the project and have met all criteria to be included as authors.
Competing interests None declared.

Patient consent Obtained.

Provenance and peer review Not commissioned; externally peer reviewed.

(C) BMJ Publishing Group Ltd (unless otherwise stated in the text of the article) 2018. All rights reserved. No commercial use is permitted unless otherwise expressly granted.

\section{REFERENCES}

1 Currarino G. Acute epitrochlear lymphadenitis. Pediatr Radiol 1977;6:160-3.

2 Barr LL, Kirks DR. Ultrasonography of acute epitrochlear lymphadenitis. Pediatr Radiol 1993:23:72-3.

3 Catalano 0, Nunziata A, Saturnino PP, et al. Epitrochlear lymph nodes: anatomy, clinical aspects, and sonography features. Pictorial essay. J Ultrasound 2010;13:168-74.

Copyright 2018 BMJ Publishing Group. All rights reserved. For permission to reuse any of this content visit

http://group.bmj.com/group/rights-licensing/permissions.

BMJ Case Report Fellows may re-use this article for personal use and teaching without any further permission.

Become a Fellow of BMJ Case Reports today and you can:

- Submit as many cases as you like

- Enjoy fast sympathetic peer review and rapid publication of accepted articles

- Access all the published articles

Re-use any of the published material for personal use and teaching without further permission

For information on Institutional Fellowships contact consortiasales@bmjgroup.com

Visit casereports.bmj.com for more articles like this and to become a Fellow 